\title{
TRANSFORMASI MANAJEMEN PEMERINTAHAN DARI ASPEK LINGKUNGAN DI KOTA BANDUNG
}

\author{
Agustinus Widanarto \\ Program Studi Ilmu Pemerintahan \\ Fakultas Ilmu Sosial dan Ilmu Politik Universitas Padjadjaran \\ e-mail: a_widanartp@yahoo.com
}

\begin{abstract}
ABSTRAK
Penelitian ini berjudul "Transformasi Manajemen Pemerintahan Dari Aspek Lingkungan di Kota Bandung". Penelitian ini dilatarbelakangi oleh baik pemerintah maupun masyarakat belum memahami kondisi dan permasalahan Kota Bandung, baik dari aspek geografis, kependudukan, pemerintahan, perekonomian dan kondisi sosial kemasyarakatannya. Penelitian ini dimaksudkan untuk mengetahui bagaimana transformasi manajemen pemerintahan dari dimensi: reframing (menata ulang), restructuring (menstruktur ulang), revitalization (menyusun ulang), dan renewal (perbaharuan) di Kota Bandung. Dalam penelitian ini digunakan metode deskriptif dengan pendekatan kualitatif. Informan dalam penelitian ini digunakan teknik purposive, yaitu terdiri dari: Wakil Ketua DPRD, Kepala Bappeda, Ketua Badan Pengelola Lingkungan Hidup, dan Direktur Utama PD Kebersihan Kota Bandung. Hasil penelitian menunjukkan bahwa dimensi reframing telah terjadi perubahan, yaitu telah ada penambahan visi daerah pada tahun 2003 dengan telah terjadinya pergantian Wali Kota Bandung. Dimensi kedua yaitu restructuring di PD Kebersihan berlangsung cukup dinamis sesuai dengan perkembangan Kota Bandung saat ini, tetapi dalam menyediakan Ruang Hijau Terbuka di Kota Bandung tidak bisa mencapai target karena lahan yang tersedia sudah dipenuhi bangunan. Pada dimensi ketiga yaitu revitalization ada sedikit dilakukan namun tidak dibarengi dengan perubahan regulasi yang memadai. Sedangkan pada dimensi keempat yaitu renewal, berkaitan dengan keadaan fisik yang secara keseluruhan belum semuanya baik. Dalam bidang sosial masih kurang ada edukasi bagi pembangunan SDM yaitu pelayanan kepada masyarakat. Kesimpulannya, transformasi manajemen dari aspek: reframing, restructuring, revilalization, dan renewal di Kota Bandung ini sudah dilakukan, tetapi belum semaksimal mungkin terutama dalam hal menyediakan Ruang Hijau Terbuka, karena ketersediaan lahan yang sudah dipenuhi bangunan.
\end{abstract}

Kata Kunci: Transformasi, Manajemen Pemerintahan, Lingkungan.

\begin{abstract}
The research is entitled "Transformation of Governmental Management from Environmental Aspect in Bandung Municipality". It was grounded in the fact that neither government nor people have understood the condition and problems of Bandung Municipality, be they are from geographic, demographic, governmental, economic, and socio-cultural condition aspects. The research was intended to find out how the transformation of government from the dimensions of reframing, restructuring, revitalization, and renewal in Bandung Municipality. The research method used was a descriptive method by a qualitative approach. The research informants were selected by using a purposive technique, consisting of: Deputy Chairman of DPRD, Head of Bappeda, Head of Environment Managing Agency, and Managing Director of PD Kebersihan of Bandung Municipality. The research findings revealed that there has been a transformation in the dimension of framing i.e., there has been an addition in local
\end{abstract}


vision from the year 2003 after the change of Bandung Mayor. The second dimension in $P D$ Kebersihan, restructuring, has been proceeding dynamically in line with the development of Bandung Municipality currently. However, in the provision of Open Green Space in Bandung Municipality, it failed to meet its target because the lands available have been full of buildings. In the third dimension, revitalization, it was slightly undertaken but not accompanied by a change insufficient regulation. Meanwhile, in the fourth dimension, renewal, relating to physical condition, it has generally been not good yet. In social aspect, there was still a lack of education on HR development, that is, services to communities. As the research conclusion, the transformation of management from the aspects of reframing, restructuring, revitalization, and renewal in Bandung Municipality has been undertaken but not yet optimal, particularly in providing Open Green Space, because lands have been full of buildings.

Keywords: Transformation, Governmental Management, Environment

\section{PENDAHULUAN}

Manajemen kepemerintahan khususnya di daerah, selayaknya ditrans- formasikan sebagaimana era modernisasi yang berlangsung dan sejalan dengan tuntutan globalisasi. Terjadinya perubahan dari pola-pola menajemen tradisional feodal yang selama ini berjalan menjadi pola manajemen pemerintahan modern yang demokratis sebagai implikasi nilai-nilai global. Pentingnya transformasi tersebut, karena implementasi manajemen pemerintahan di daerah tidak lepas dari sistem politik global dan nasional.

$$
\text { Transformasi merupakan }
$$

proses peralihan dari suatu masa tertentu ke masa selanjutnya yang terjadi karena adanya inovasi atau perubahan-perubahan baik struktural maupun prosedural, terencana maupun tidak terencana. "Transformasi pada dasarnya merupakan proses yang berlangsung terus-menerus. Transformasi ini meliputi mengkerangkaulang/refroming, menstrukturulang/restructuring, menyusun-ulang prioritas pembangunan/ revitalization dan pembaharuan/ renewal", (Gouilart:1995). Wujud yang paling nyata dari tugas, kegiatan atau fungsi yang dilaksanakan oleh suatu sistem pemerintahan adalah pelayanan masyarakat. Keseluruhan aspek pemerintahan negara yang meliputi aspek kelembagaan, ketatalaksanaan dan sumber daya manusia, senantiasa mengarah kepada upaya peningkatan efisiensi dan profesionalisme fungsi pelayanan. Tugas umum pemerintahan dan pembangunan memiliki pengertian yang saling memperkuat karena pelayanan kepada masyarakat dalam arti yang seluas-luasnya merupakan hakekat dati tugas umum pemerintahan itu sendiri.

Ndraha menunjukkan hubungan pemerintah (governance relations), yaitu hubungan yang terjadi antara yang diperintah dengan pemerintah satu terhadap yang lain pada satu posisi dan peran. Dalam kaitan itu, kualitas pelayanan menjadi gejala atau masalah yang sering mewarnai 
interaksi tersebut. Untuk itu pemerintah bukan lagi penentu kualitas pelayanan, akan tetapi masyarakat sebagai pelanggan kebutuhan dan kepentingan yang ditawarkan pemerintah. Pelangganlah yang paling tahu mana yang baik untuk kehidupannya. Seperti dikemukakan Couper (dalam Osborne dan Gaebler, 1992:166), bahwa "Quality is determined only by costumers". Dalam kaitan itu, Couper (dalam Osborne dan Gaebler, 1992: 169,172), dikatakan pemerintah perlu: Getting close to the costumer, because the costumer are the most important people for an organization".

Dengan demikian baik buruknya produk layanan masyarakat yang diberikan, lebih banyak bergantung pada sejauh mana tanggapan atau kepuasan penerima pelayanan. Hal ini adalah sangat wajar karena sesuai dengan misi Kota Bandung yaitu : Meningkatkan kualitas lingkungan hidup, yaitu merupakan upaya pemerintah kota untuk memenuhi kebutuhan dasar penduduk mulai dari penyediaan air bersih baik secara kuantitas maupun kualitas, menyediakan sarana dan prasarana lingkungan yang memenuhi standar teknis/Standar Pelayanan Minimal (SPM), meningkatkan kualitas udara, penataan ruang kota yang berkualitas, mengembangkan sistem transportasi yang dapat menjamin keselamatan, efisien, nyaman dan ramah lingkungan.
Wilayah Kota Bandung dilihat dari berbagai aspek merupakan wilayah yang mempunyai letak strategis, baik untuk tempat tinggal, untuk mengembangkan usaha maupun untuk pendidikan. Akan tetapi, letak yang strategis ini dapat memberikan dampak yang negatif terhadap pemerintah Kota Bandung, seperti penambahan jumlah penduduk yang tidak terkontrol dan tertata rapi, yang berdampak pada kurang berkualitasnya pelayanan masyarakat.

Untuk

memahami permasalahan di Kota Bandung ini, maka baik pemerintah maupun masyarakat perlu memahami kondisi dan permasalahan Kota Bandung baik dari aspek geografis, kependudukan, pemerintahan, perekonomian dan kondisi sosial kemasyarakatannya.

Penyelenggaraan pembangunan di Kota Bandung dalam kurun waktu tahun 20013-2018 menghadapi permasalahan yang masih perlu ditingkatkan atau dikembangkan. Isu-isu strategis yang menjadi prioritas pembangunan Kota Bandung dan menjadi agenda utama rencana pembangunan daerah dalam 5 (lima) tahun ke depan adalah: 1) Pertumbuhan penduduk dan persebarannya. 2) Kualitas dan aksesibilitas pendidikan dan kesehatan. 3) Pengangguran dan ketenagakerjaan. 4) Pertumbuhan ekonomi dan pemerataan kesejahteraan masyarakat. 5) Kualitas dan cakupan pelayanan infrastruktur 6) Kualitas lingkungan 
hidup untuk mendukung terwujudnya Jawa Barat Green Province. 7) Kualitas demokrasi dan Pemilu Nasional tahun 2014. 8) Adaptasi dan mitigasi terhadap bencana dan perubahan iklim. 9) Pemerintahan daerah yang efektif dan efisien. 10) Penyelenggaraan Pekan Olahraga Nasional Tahun 2016. 11) Perlindungan Hukum dan Hak Asasi Manusia (HAM). 12) Penegakan dan harmonisasi produk hukum. 13) Pengelolaan aset daerah. 14) Pelestarian Budaya Lokal. 15) Pengembangan Industri Wisata Jawa Barat. 16) Harmonisasi Perencanaan Pusat, Provinsi dan antar Kabupaten/Kota. 17) Daerah Perbatasan. 18) Penanggulangan penduduk miskin. 19) Pasar global dan Asean - China Free Trade Area (ACFTA) 20) Keterbatasan energi dan pengembangan energi baru dan terbarukan. 21) Peranserta masyarakat terhadap budaya daerah dan penanganan masalah sosial. 22) Pemerataan pembangunan antar daerah. 23) Alih fungsi lahan dari pertanian ke non pertanian.

Tujuan khusus dari penelitian ini adalah terwujudnya perubahan manajemen pemerintahan Daerah Kota Bandung yang tepat dan strategis. Transformatif manajemen pemerintahan Kota Bandung memiliki urgensi untuk menjadi fokus kajian dalam menata pemerintahan di Indonesia. Demokratisasi akan lebih bermakna karena ada blue print yang baru mengenai kerangka dan struktur pemerintahan dan juga pemerintahan daerah yang harus menentukan prioritas dengan nilai pembaharuan.

\section{TINJAUAN PUSTAKA}

Transformasi manajemen pemerintahan pada dasarnya merupakan inovasi-inovasi yang dilakukan oleh pemerintah guna mengadakan perubahan di bidang struktural dan prosedural. Inovasi struktural berhubungan dengan perubahan yang menyangkut kelembagaan, sementara inovasi prosedural berhubungan dengan berbagai perubahan di bidang mekanisme kepemerintahan. Inovasi struktural dan prosedural ini dimaksudkan agar kepemerintahan dapat berlangsung sesuai tuntutan rakyat dan menciptakan suatu kondisi bagi rakyat untuk mengembangkan kemampuan dan kreativitasnya sendiri. Hal ini sangat bergantung pada individu dan pola pengelolaan manajemennya sendiri, yaitu manajemen pemerintahan yang merupakan kunci bagi berhasilnya proses transformasi manajemen pemerintahan tersebut. Kemampuan manajer pemerintahan untuk menyelenggarakan perubahanperubahan itulah yang akan menunjukkan kualitas dari manajemen pemerintahnnya.

$$
\text { Inovasi-inovasi dalam }
$$

transformasi tersebut, meliputi reframing, re-structuring, revitalizaton dan re-newal (Gouillart dan Kenny, 1995 : 1-14). sebagai suatu proses yang mendahului berbagai perubahan-perubahan tersebut. 
Reframing (pengubahan

kerangka berpikir) yaitu suatu dimensi transforming organisasi dalam peningkatan konsepsi perusahaan (company) tentang sesuatu masalah yang dihadapi dan bagaimana langkah-langkah yang perlu ditempuh untuk mengatasinya.

Organisasi sering memperoleh cara tertentu dari pemikiran yang kurang tepat dan kehilangan kemampuan untuk mengembangkan model-model pemikiran baru (alternatif) tentang masalah apa sebenarnya yang dihadapi dan apa saja yang dapat diperbuat. Dengan demikian, organisasi selaklu berusaha membuka pikiran (mind) serta memasukkannya dalam visi baru dalam rangka mengantisipasi masalah-masalah internal dan eksternal organisasi yang terus menerus berubah.

Retructuring (pengubahan struktur) yaitu suatu dimensi transformasi organisasi pada suatu organisasi menghadapi persaingan kinerja (performance) dengan cara mengubah besaran agar organisasi dapat berjalan dengan lincah. Pertimbangan utamanya adalah bagaimana mengatur keseimbangan dalam organisasi misalnya keseimbangan pemberian penghasilan karyawan dengan prestasi kerja dan pengabdiannya. Jadi dalam hal ini organisasi selalu menggunakan keunggulan untuk menerapkannya dalam programprogram perubahan (transformation) dalam jangka waktu yang lebih lama.
Revitalization (memberdayakan kembali) merupakan suatu dimensi transformasi organisasi dimana organisasi memelihara pertumbuhannya dengan cara mengaitkan besaran organisasi terhadap lingkungan organisasi. Untuk meningkatkan pertumbuhan organisasi harus pula diperhatikan sumber-sumber daya yang tersedia.

Renewal (pembaharuan) yaitu suatu dimensi transformasi organisasi yang beroriensasi pada transformasi orang (people) dan jiwa dari perusahaan (company), dengan cara membangun keahlian dan tujuan baru, sehingga perusahaan dapat mengatasi dirinya sendiri.

Dari empat pokok pikiran tentang transformasi organisasi di atas, terlihat bahwa organisasi sebagai organ hidup layaknya manusia yang mempunyai kebutuhan yang kompleks. Organisasi berada dalam lingkungan yang terbuka dapat mempengaruhi dan dipengaruhi oleh lingkungannya. Oleh karena itu organisasi harus selalu melakukan transformasi sesuai dengan perubahan lingkungan.

Konsep-konsep dari transformasi organisasi tersebut dipandang relevan untuk dapat diterapkan dalam penataan organisasi pemerintah daerah dengan penyesuaian pada kebutuhan dan kondisi daerah.

Evolusi manajemen pemerintahan di atas merupakan proses transformasi manajemen pemerintahan, menunjukkan bahwa manajemen pemerintahan tidaklah 
statis (stagnant) ia mengikuti gerak dinamika rakyatnya yang selalu berubah dan selalu menginginkan perubahan sesuai tuntutan yang berkembang pada masa itu. Dan manajemen pemerintahan dalam kerangka melaksanakan perannya tidak dapat lepas dari berbagai inovasi yang terus-menerus dan kegiatan-kegiatan yang mendahuluinya, sebagaimana telah dikemukakan sebelumnya yang meliputi kegiatan-kegiatan menyusun kerangka pemerintahan yang baru melalui perubahan visi dan misi pemerintahan yang secara teoritis disebut kegiatan reframing. Kemudian kegiatan dalam kerangka struktur guna menampilkan kinerja pemerintahan yang sesuai dengan kebutuhan masyarakat yang dipadukan dengan keharusan kebijakan yang lebih atas yang mengaturnya, secara teoritik aktifitas ini disebut sebagai kegiatan restructuring. Aktivitas transformasi berikutnya adalah pada penyusunan kerangka prioritas pemerintahan. Hal ini berkait dengan target dan tujuan pemerintahan diadakan, dalam konsep teori kegiatan ini disebut sebagai revitalization dan terakhir pada kegiatan pembaharuan atau reneval.

Inovasi-inovasi dalam bentuk aktivitas di atas dalam hubungannya dengan internal pemerintahan maupun dalam hubungan kekuasaan merupakan unsur utama transformasi manajemen pemerintahan, sehingga dapat terus-menerus mengikuti perubahan dan tuntutan masyarakatnya. Hal itu dilakukan untuk tetap dapat mempertahankan etika pemerintanannya, yaitu:public trust, objective judgement, accountability, democratic leadership and respectability. (The Government Ethnics Center of Josepshon Institute og Ethnics, 1966:25).

Melihat fenomena transformasi manajemen pemerintahan di atas, maka secara teoritik dapat dikatakan bahwa hubungan pemerintah dibangun melalui sinergisme dan kerjasama informal, kepaduan dan sinkronisasi tindakan, nilai-nilai kebersamaan dan komitmen, serta pola sistem keluarga/clan. Dengan kata lain menurut Institute on Governance (makalah, 1976) hubungan pemerintahan dibangun melalui kerangka kerjasama tim (teamwork), hubungan kemitraan (partnership), kerjasama (cooperation), keberanian mengambil resiko (risk taking) dan komitmen terhadap nilai-nilai internal (commitment to internally values) (lihat juga Kooiman, 1993: 249-262). Dan manajemen pemerintahan itu sendiri harus didasarkan pada equity (kewajaran), fairness (keadilan) dan effectiveness (efektifitas) (Ott, 1990 : xi).

Manajemen pemerintahan yang didasarkan pada kewajaran, keadilan dan efektivitas mengacu pada konsep pembangunan politik, sebagaimana disebut oleh Lucian W.Pye (1966:4547) yang mengindikasikan pada 3 (tiga) hal, yaitu tercapainya equality (kesamaan), differenciation and 
specialization (adanya pembedaan dan pengkhususan lembaga) serta capacity (kemampuan untuk mengefektifkan dan stabilisasi). Dengan demikian manajemen pemerintahan yang wajar, adil dan efektif adalah manajemen pemerintahan sebagai suatu rangkaian proses dari pembangunan politik menuju pemerintahan yang demokratis, artinya adanya accountabilty (akuntabilitas), transparancy (transparan), opennes (terbuka) dan rule of law (berdasarkan hukum yang berlaku)" (Camdessus, 1998:2).

Dari pendapat-pendapat di atas, maka: pertama, manajemen pemerintahan yang wajar dikategorikan sebagai manajemen pemerintahan yang akuntabel karena dibangun di atas landasan kesamaan dengan kata lain kewajaran manajemen dapat dilihat dari kinerja pemerintahan tersebut; kedua, manajemen pemerintahan yang adil dikategorikan sebagai manajemen yang transparan dan terbuka karena dibangun di atas landasan kompetensi kelembagaan yang diperbedakan dan dikhususkan pada masing-masing fungsi. Hal ini dapat dilihat dari keadilan manajemen pemerintah dalam pelayanan publik. Ketiga, manajemen yang efektif adalah manajemen pemerintahan yang berorientasi pada kepaduan dan kemampuan menggerakkan pembangunan. Efektifitas manajemen tersebut diindikasikan oleh kemampuan manajemen pemerintahan dengan asumsi bahwa selama proses pergantian manajer kota dilakukan secara demokratis, maka dapat diperkirakan bahwa manajemen kota memiliki kemampuan untuk menyelenggarakan pemerintahan kota.

\section{METODE PENELITIAN}

Peneliti memilih metode
penelitian deskriptif pendekatan kualitatif dikarenakan fokus penelitian ini adalah ingin melihat bagaimana proses manajemen pemerintahan di Kota Bandung dalam upaya menciptakan good governance. Dengan demikian dapat dikatakan bahwa penelitian deskriptif merupakan penelitian yang berusaha mendiskripsikan suatu gejala, peristiwa yang terjadi pada saat sekarang atau masalah aktual.

Pemilihan pendekatan kualitatif untuk mendapatkan gambaran dan uraian yang jelas, sistematis, faktual, akurat dan valid mengenai penyusunan road map manajemen pemerintahan dalam upaya mewujudkan good governance di pemerintah Kota Bandung. Transformasi manajemen pemerintahan yang ada dalam penelitian ini, yaitu sebagai berikut:

1. Lingkungan internal manajemen pemerintahan. Lingkungan internal yang berpengaruh secara timbal balik terhadap manajemen pemerintahan, yaitu sebagai berikut:
a. Visi dan misi organisasi;
b. Budaya organisasi; 
c. Organisasi/ pemerintahan bayangan;

d. Hubungan dengan subsistem dan sub-subsistemnya.

2. Lingkungan fisik dan non-fisik

a. Lingkungan fisik

b. Lingkungan nonfisik

Penentuan informan dilakukan berdasarkan informasi awal mengenai penerapan road map tersebut. Informan pangkal dalam penelitian ini adalah orang atau sekelompok orang yang dipandang mampu memberikan informasi secara umum mengenai penyusunan road map manajemen pemerintahan dalam upaya mewujudkan good governance di Kota Bandung dan mampu menunjukkan orang lain sebagai informan kunci yang memberi informasi lebih mendalam. Jadi informan kunci merupakan seseorang atau sekelompok orang yang direkomendasikan oleh informan pangkal.

Teknik penentuan informan yang digunakan dalam penelitian ini adalah purposive (pengambilan informan berdasarkan tujuan). Dalam hal ini peneliti menentukan anggota informan berdasarkan pertimbangan peneliti sendiri yang sesuai dengan maksud dan tujuan penelitian. Adapun informan yang dilibatkan dalam penelitian ini adalah:

1. Wakil Ketua DPRD Kota Bandung

2. Kepala Badan
a. Bappeda
b. BPLHD

3. Direktur PD Kebersihan
Analisis data yang digunakan dalam penelitian ini adalah analisa deskriptif dengan pendekatan kualitatif. Data dikumpulkan terlebih dahulu sebelum diinterprestasikan. Artinya data diproses terlebih dahulu melalui prosedur atau pentahapan yang sistematis.

Teknik analisa data adalah proses penyusunan data agar ditafsirkan. Menyusun berarti menggolongkan ke dalam pola, tema dan kategori. Tafsiran berarti memberikan makna analisis , menjelaskan pola dan menggabungkannya dengan berbagai konsep yang kemudian hasilnya dituangkan ke dalam bentuk katakata dan bukan angka-angka sehingga metode analisa data yang digunakan adalah metode deskriptif dengan pendekatan kualitatif.

\section{HASIL PENELITIAN DAN PEMBAHASAN}

\section{Reframing}

Berdasarkan hasil wawancara dengan Wakil Ketua DPRD, Kepala Bappeda, Staf Badan Pengelolaan Lingkungan Hidup, dan Direktur PD Kebersihan, diperoleh informasi yang saling mendukung tentang apakah telah terjadi reframing transformasi pemerintahan di Kota Bandung. Dasar hukum visi dan misi pemerintah Kota Bandung adalah Peraturan Daerah Kota Bandung Nomor 03 Tahun 2014 tentang Rencana Pembangunan Jangka Menengah Daerah Tahun 2013-2018. Dalam Peraturan Daerah tersebut disebutkan bahwa visi Kepala Daerah 
Tahun 2013-2018 yaitu Terwujudnya Kota Bandung Yang Unggul, Nyaman dan Sejahtera, sejalan dan selaras dengan Visi Daerah yaitu 'Kota Bandung Yang Bermartabat'. Artinya telah ada penambahan visi dari visi daerah sebelumnya, sehingga dapat dikatakan telah ada reframing dengan pergantian Walikota Bandung pada tahun 2013 dari Dada Rosada kepada Ridwan Kamil.

Konsep visi yang merupakan reframing baru itu adalah konsep unggul, nyaman, dan sejahtera. Unggul yaitu menjadi yang terbaik dan terdepan serta contoh bagi daerah lain dalam upaya terobosan perubahan bagi kenyamanan dan kesejahteraan warga Kota Bandung. Nyaman yaitu terciptanya suatu kondisi dimana kualitas lingkungan terpelihara dengan baik, serta dapat memberikan kesegaran dan kesejukan bagi penghuninya. Kota yang nyaman dimana kebutuhan dasar manusia seperti tanah, air dan udara terpenuhi dengan baik sehingga nyaman untuk ditinggali. Sejahtera dan berkualitas yaitu mengarahkan semua pembangunan kota pada pemenuhan kebutuhan lahir dan batin wargaa, agar manusia dapat memfungsikan diri sebagai hamba dan wakil Tuhan di bumi.

Menurut Kepala Bappeda Kota Bandung, bahwa sejahtera itu menyangkut ke masalah ekonomi jadi wealthy, kemakmuran, sejahtera. Jadi semua pasti cocok dan semua upaya pemerintah pada umumnya di semua kota pasti akan mengarah ke sana. Yang menyusun visi dan misi itu kan Bappeda. Jadi di Bappeda sendiri mewujudkan Perencanaan yang Berkualitas dan Aspiratif. Jadi seolah-olah aspiratif dan berkualitas itu dipisah, tetapi intinya tidak.

Dalam menghadapi perubahan global di Kota Bandung ada yang memang harus disesuaikan. Sebetulnya lembaga itu sebagai sebuah sarana untuk mencapai tujuan, tentu saja ada beberapa yang harus di adjust, ditambah, dihilangkan, dikurangi. Problemnya pemerintah daerah itu kan tidak diberikan suatu otonomi yang cukup untuk mengatur kelembagaan.

Dari aspek Lingkungan Hidup, menurut pihak BPLH, di Kota Bandung prioritasnya fisik seperti taman. Jadi BPLH selain sebagai perumus kebijakan di bidang lingkungan, ada kegiatan adipura, dengan menunjang sarana prasarana sampah seperti komposter. BPLH membantu melalui gerakan-gerakan yaitu gerakan memungut sampah, agar mendorong masyarakat untuk mengurangi sampah. BPLH mempunyai rencana aksi daerah dalam menghadapi perubahan iklim melalui mitigasi dan adaptasi perubahan iklim.

Kalau BPLH sebenarnya merumuskan kebijakan, yaitu memberikan kebijakan tentang lingkungan hidup dari perencanaan sampai rehabilitasi. Mereka membantu melalui gerakan-gerakan misalnya gerakan memungut sampah dan mendorong masyarakat untuk mengurangi sampah. Sebenarnya sekarang sudah terjadi perubahan 
perilaku dengan kepemimpinan yang baru. Lalu dengan hadirnya sosial media bisa memunculkan semangat masyarakat untuk ikut melakukan sesuatu. Di BPLH punya rencana aksi daerah dalam menghadapi perubahan iklim melalui mitigasi dan adaptasi perubahan iklim. Mitigasi yaitu pencegahan kalau adaptasi menyesuaikan setelah terjadi perubahan iklim. BPLH punya RAD Kota Bandung, isinya konsepkonsep. Mereka mengajak semua dinas dalam lingkungan Pemerintah Kota Bandung untuk melakukan suatu kegiatan melalui mitigasi dan adaptasi perubahan iklim.

Implikasi semakin padatnya penduduk di Kota Bandung mendorong kota ini untuk terus melakukan pembangunan fisik untuk memenuhi kebutuhan dari masyarakat yang ada didalamnya. Pembangunan tersebut baik yang dilakukan pemerintah dengan orientasi pelayanan maupun oleh pihak swasta yang berorientasi keuntungan. Pembangunan fisik di Kota Bandung saat ini berkecenderungan didominasi oleh pihak swasta. Misalnya saja pembangunan apartemen, hotel, restoran, pusat pembelanjaan, dll.

Menurut peneliti, idealnya pembangunan yang ada tidak mengabaikan keseimbangan alam di Kota Bandung. Keseimbangan alam tersebut dapat diwujudkan dengan tersedianya jumlah Ruang Terbuka Hijau yang memadai di Kota Bandung. Namun sayangnya semakin banyaknya pembangunan di
Kota Bandung berdampak pada semakin sedikit pula lahan yang dapat digunakan untuk ruang terbuka hijau. Ruang Terbuka Kawasan Perkotaan itu sendiri berdasarkan Permendagri No. 1 Tahun 2007 adalah "bagian dari ruang terbuka suatu kawasan perkotaan yang diisi oleh tumbuhan dan tanaman guna mendukung manfaat ekologi, sosial, budaya, ekonomi dan estetika."

Mengingat pentingnya Ruang Hijau Terbuka Kawasan Perkotaan, dalam Undang-undang No. 26 Tahun 2007 pasal 29 ayat (2) dan (3) diatur mengenai proporsi RTH pada wilayah kota paling sedikit 30 (tiga puluh) persen dari luas wilayah kota. Sebagai turunan dari Undang-undang tersebut, Pemerintah Kota Bandung sudah mengatur dalam Peraturan Daerah Kota Bandung No. 18 Tahun 2001 tentang Rencana Tata Ruang Wilayah Kota Bandung. Namun pada kondisi di lapangan, jumlah ruang terbuka hijau di Kota Bandung pada tahun 2013-2015 belum terdapat $30 \%$ Ruang Terbuka Hijau, tetapi kini baru tersedia $9 \%$.

Adapun menurut Direktur Utama PD Kebersihan Kota Bandung, bahwa Kota Bandung akan menciptakan Kota Bandung bersih dalam 20 tahun. Sedangkan PD Kebersihan mempunyai visi tersendiri, yaitu menciptakan Bandung bersih pada Tahun 2025, artinya visi misi yang dibuat menginduk kepada visi misi Kota Bandung. Jadi memang salah satu visi dan misi yang ada termasuk juga dalam RPJMD juga 
mangatakan bahwa Bandung ini harus ramah lingkungan dan bersih. Visi misi kalau menurutnya, visi misi aplikasi dari walikota terpilihnya. Visi misi ini dibuatnya sejak Ridwan Kamil dan pa Oded terpilih jadi walikota dan wakil walikota, hanya ada satu kaitannya yang pas dengan PD kebersihan itu adalah memang membangun maksudnya ada orientasi irisan terhadap lingkungan, lingkungan ini kan banyak, salah satunya kalau berbicara lingkungan adalah kebersihan, jadi memang salah satu visi misi yang ada termasuk juga dalam RPJMD juga mengatakan bahwa Bandung ini kan harus ramah lingkungan dan bersih, kalau ini secara struktur PD kebersihan ini beda dengan SKPD - SKPD beda dengan BPLH, DISYANJAK itu beda. PD Kebersihan adalah perusahaan daerah jadi statusmya adalah badan usaha milik daerah yang sahamnya milik perusahaan kota sehingga memang lebih banyak kepada dua hal yang satu adalah pelayanan publik tentang kebersihan, yang kedua adalah bisnis, jadi misi ini sangat sesuai dengan salah satu visi Kota Bandung ingin menciptakan daerah yang memang bersih.

PD Kebersihan akan menciptakan Bandung yang bersih dalam 20 tahun, visi nya ketika terpilih yaitu menciptakan Bandung bersih pada tahun 2025 ya sepuluh tahun sih, tapi memang langkah langkahnya misi - misi nya adalah banyak yaitu punya beberapa langkah salah satunya menciptakan Bandung bebas sampah jadi artinya visi misi yang dibikin menginduk kepada visi misi Kota Bandung.

Itu ada dasar hukumnya jelas di PD Kebersihan ada Perda kebersihan yang mengatur adanya visi dan misi walaupun memang visi misi itu kadang dirubah disesuaikan dengan pejabat baru, karena Direktur Utama PD Kebersihan menjabat baru juga, jadi visi misinya sedikit dirubah.

Demikian pula dengan Badan Pengelolaan Lingkungan Hidup (BPLH) Kota Bandung, prioritas pembangunan Lingkungan Hidup ialah di bidang fisik dan taman. Seperti kita lihat sekarang ini, dimana-mana sudah dan sedang dibangun taman dan pemasangan lampu jalan. Jadi BPLH selain sebagai perumus kebijakan, ada kegiatan adipura, dengan menunjang sarana dan prasarana sampah seperti komposter. BPLH membantu melalui gerakan-gerakan misalnya gerakan memungut sampah, dan mendorong masyarakat untuk mengurangi sampah.

Hal ini sesuai dengan misi Kota Bandung yaitu : Meningkatkan kualitas lingkungan hidup, yaitu merupakan upaya pemerintah kota untuk memenuhi kebutuhan dasar penduduk mulai dari penyediaan air bersih baik secara kuantitas maupun kualitas, menyediakan sarana dan prasarana lingkungan yang memenuhi standar teknis/Standar Pelayanan Minimal (SPM), meningkatkan kualitas udara, 
penataan ruang kota yang berkualitas, mengembangkan sistem transportasi yang dapat menjamin keselamatan, efisien, nyaman dan ramah lingkungan. Namun demikian, misi tersebut tidak akan bisa tercapai apabila semua usaha yang dilakukan oleh PD. Kebersihan maupun BPLH tersebut tidak didukung dan tanpa adanya partisipasi dari masyarakat Kota Bandung.

Untuk mencapai visi itu PD Kebersihan merubah logo, merubah uniform, merubah branding dan sebagainya, dan itu sudah dilakukan sejak bulan Agustus 2015 yang lalu. Jadi memang PD Kebersihan mempunyai misi ingin tampil beda setelah 30 tahun. Lebih bersih, lebih smart, lebih bisa diterima oleh publik. Kebetulan walikotanya sekarang orang teknik, jadi biasanya melihat visual beda dengan orangorang sosial seperti kita biasanya melihat perilaku ini dan itu perlu waktu lama untuk merubah perilaku itu biasanya perlu waktu 20 atau 30 tahun, tetapi orang teknik biasanya melihat ada di depan mata kemudian dia merubah jadi sesuatu yang perubahannya cepat biasanya itu perlu branding, seperti membangun taman-taman kemudian tanah-tanah kosong dijadikan sarana publik, termasuk juga dengan membuat Bandung bersih ini salah satunya dengan mobil sapu. Pegawai yang tadinya kerjanya jam 06 pagi, ditarik menjadi jam 04 subuh, kemudian ada 3 sift yang bekerja di alun-alun.

Demikian pula dengan efisiensi bahwa dalam 4 bulan ini PD
Kebersihan telah melakukan rotasi dan melakukan inovasi seperti bank sampah, truk-truk yang sudah lama diganti dan penggunaan kantong kresek yang ramah lingkungan sehingga bisa menghemat 200 ton perhari kantong kresek. Menurut rencana 100 kendaraan truk PD Kebersihan itu termonitor karena sekarang sedang bekerjasama dengan Telkom, bahkan bayar tol juga pakai chips khusus bahkan sekarang sudah dilakukan efisiensi dengan bekerjasama dengan SPBU-SPBU, jadi sekarang para sopir tidak diberi uang untuk beli solar, sehingga 2 sampai 3 tahun lagi pada PD Kebersihan akan lain dengan PD Kebersihan yang dulu.

Sekarang ini di semua RW di wilayah Kota Bandung ada Program Inovasi Pembangunan dan Pemberdayaan Kewilayahan (PIPPK), yaitu antara lain bahwa di setiap RW pada Tahun 2015 telah diberi bantuan berupa sebuah sepeda motor roda 3 yang digunakan untuk mengangkut sampah dari rumah tangga ke TPA, dan pada tahun 2016 ini diberikan bantuan dengan program yang lain.

Adapun sebagai prioritas pembangunan Kota Bandung adalah konsentrasi untuk mendapatkan Adipura karena peraihan adipura kan otomatis semua terkonsentrasi ke sana, karena bersih itu harus selalu terjaga. Ternyata pada akhir tahun 2015 ini, Kota Bandung benar-benar mendapatkan penghargaan Adipura. Hal ini menunjukkan bahwa semua pihak telah benar-benar berusaha 
untuk mendapatkan Adipura melalui Reframing di berbagai SKPD maupun lembaga-lembaga yang ada di Kota Bandung.

\section{Restructuring}

Berdasarkan hasil wawancara dengan Wakil Ketua DPRD Kota Bandung, Kepala Bappeda, Badan Pengelolaan Lingkungan Hidup dan Direktur Utama PD Kebersihan, diperoleh informasi bahwa walaupun telah terjadi adanya reframing terhadap visi dan misi Kota Bandung namun tidak disertai adanya restructuring atau penataan kembali lembaga-lembaga yang ada di Kota Bandung. Hal ini tentu patut disayangkan sebab motor untuk menggerakkan ide-ide itu agar terwujud dalam kenyataan adalah adanya organisasi atau lembaga.

Informan dari Wakil Ketua DPRD menganggap keberadaan kelembagaan yang ada di lingkungan Pemerintah Kota Bandung sudah cukup memadai untuk dapat melaksanakan seluruh kewenangan dan urusan yang menjadi urusan dan kewenangan Pemerintah Kota Bandung. Demikian pula keberadaan jabatan yang ada di Kota Bandung sudah cukup memenuhi standar yang ditetapkan dalam Peraturan Pemerintah No. 41 Tahun 2007 tentang Organisasi Perangkat Daerah, sehingga tidak perlu ada jabatan baru. Namun menurut Ketua Bappeda, ya memang harus disesuaikan, karena sebenarnya lembaga itu sebuah sarana untuk mencapai tujuan, tentu saja ada beberapa yang harus ditambah, dihilangkan, dan dikurangi. Problimnya pemerintah daerah itu tidak diberikan suatu otonomi yang cukup untuk mengatur kelembagaan, jadi semuannya sudah diatur oleh MENPAN. Padahal setiap daerah itu punya kebutuhan yang berbeda.

Kota Bandung skalanya bagaimana, kota kecil bagaimana. Di satu sisi kalau tidak dibatasi masalahnya akan menjadi beban juga. Kalau kelembagaan itu erat kaitannya juga dengan menyediakan orangnya, sarana, gaji, dan sebagainya, sehingga kecenderungannya kita memang selalu ingin membentuk banyak posisi yang sifatnya struktural. Hal ini sejalan dengan pendapat peneliti bahwa setiap perubahan visi dan misi mesti juga dipikirkan untuk adanya restructuring untuk mengimbangi perubahan dalam reframing tersebut.

Mengenai keberadaan jabatanjabatan yang ada di lembaga ini, menurut Kepala Bappeda perlu ada jabatan baru, hanya Kepala Bappeda tidak memiliki keleluasaan untuk melakukan itu karena sudah diatur, seperti sekarang ada perintah untuk tidak boleh melakukan perubahan SOTK, padahal sudah banyak yang ini harus dikeluarkan dulu, bagian ini harus dibentuk ini dan sebagainya. Kita menganjurkan kelembagaan ini juga diatur oleh pusat.

Mengenai Tupoksi kalau di Bappeda tumpang tindih tidak ada. Bahkan ada yang tidak ada yang menangani, seperti public private partnership, karena walikota Bandung sekarang ini menggarap 
strategi utamanya kolaborasi, desentralisasi dan inovasi, sehingga wajah Kota Bandung secara fisik sejak kepemimpinan Ridwan Kamil mengalami perubahan, terutama di pusat-pusat kota, antara lain banyaknya taman kota, adanya kursikursi di pinggir jalan, sehingga masyarakat Kota Bandung lebih nyaman bila jalan-jalan di pusatpusat kota.

Tantangan dan hambatan dalam Tupoksi, di sekretariat daerah ada kerjasama, tetapi sepertinya belum bisa mengikuti progresifitas walikota yang banyak kerjasama dengan luar negeri. Biasanya di Bappeda ada, namanya Perencanaan Kerjasama, ditangani pada level subdit. Itupun kita memiliki kapasitas yang terbatas jadi mungkin lebih ke kapasitas dalam arti bisa SDM-nya, bisa kewenangannya. Jadi mungkin harus ada penguatan dalam kerjasama itu.

Sedangkan di BPLH, kurangnya sub bagian program, dan kurang bidang penegakan hukum. Namun menurut peneliti, BPLH tidak bekerja sendirian. Mereka bekerja bersama-sama dengan lembaga lain, termasuk para SKPD dan juga termasuk Satpol PP yang bertugas khusus di bidang penegakan hukum. Di BPLH, sebenarnya terjadi tumpang tindih antara BPTLH dengan RLH. Misalnya, pengawasan di lapangan, apabila ada pengaduan, BPLH tidak punya bidang penegakan hukum. Bidang rehabilitasi volume kegiatannya agak kurang jadi dilempar ke yang lain. Kami tidak bekerja sendirian, dibantu oleh hadirnya LSM, sekolah-sekolah, sampai pada tingkat kelurahan. Selain itu contoh lain adalah sweeper sampah, BPLH yang mengadakan, tetapi dilempar ke PD Kebersihan, sebenarnya tidak boleh karena berkaitan dengan penyerahan penyertaan modal. Regulasinya tidak ada, jadi bingung.

Mengenai tumpang tindih kewenangan, di BPLH sedikit-sedikit ada. BPLH dengan PD Kebersihan, dan dengan Dinas Pertamanan. Misalnya di BPLH ada pengadaan pohon, di Dinas Pertamanan juga ada. padahal tujuannya beda tetapi secara sepintas sama. Jadi mereka suka gabung dengan Dinas Pertamanan dan PD Kebersihan, jadi "Trio LH". Di PD Kebersihan, terhadap pertanyaan : Bagaimana pendapat Bapak tentang kelembagaan yang ada di Kota Bandung, Direktur Utama PD Kebersihan merasa tidak tahu, tetapi kadang-kadang ia melihat ada SKPD yang tumpang tindih. Jadi ada pekerjaan yang bisa diefisienkan dikerjakan oleh satu dinas tetapi kalau gemuk dikerjakan oleh dinas yang lain, kemudian itu menambah cost kan sehingga SKPD ini bergantung kebutuhan, jadi ada kesan SKPD itu menghabiskan anggaran.

Mengenai pertanyaan apakah tupoksi lembaga sudah jelas, kata Direktur Utama PD Kebersihan sudah jelas. Tantangannya ada di masyarakat. PD Kebersihan melakukan inovasi dengan membuat 
tong sampah kodok di sepanjang jalan, umurnya hanya 3-4 bulan, karena diambil orang. Artinya bagaimana perlu merubah perilaku masyarakat. Contoh kedua, PD Kebersihan membuat taman yang cukup bagus di alun-alun, ternyata waktu takbiran atau waktu pawai PERSIB menjadi kotor sekali, nah itu tantangan terbesar terutama edukasi.

Kalau ditanya seberapa penting perusahaan ini, dijawab oleh Direktur Utama Kebersihan bahwa kalau satu hari sampah di Kota Bandung tidak diangkut kemudian disimpan di suatu tempat, lapangan gasibu itu tertutup semua oleh sampah Kota Bandung satu meter tingginya. Kalau dua hari berarti dua meter, kalau tiga hari berarti tiga meter. Bayangkan, orang menganggap remeh soal sampah dan PD Kebersihan. Kalau PD Kebersihan satu hari mogok ...Dulu, kasus Leuwigajah Tahun 2005, dalam satu minggu Bandung dicap sebagai Bandung Lautan Sampah. Kalau sampah, jangankan berbulanbulan, tiga atau empat hari tidak diangkat, sudah bau. Kalau organik itu tiga hari langsung keluar belatung. Jadi kalau ditanya seberapa penting PD Kebersihan itu sangat penting.

\section{Revitalization}

Pemahaman responden tentang potensi alam, potensi SDM, dan potensi Sumber daya buatan di Kota Bandung, menurut wakil ketua DPRD Kota Bandung bahwa di Kota Bandung ini tidak punya SDA yang bisa dijadikan bahan tambang dsb. Kalau seperti bangunan-bangunan heritage itu sumber daya buatan. Kita mengandalkan SDM. Sebenarnya SDM kita lumayan kualitasnya, yaitu usia produktif, kita lebih kompetitif, hanya memang perlu diarahkan ke sektor-sektor yang ekonomi kreatif, karena kita unggul di sana selain teknologi informasi. Makanya SDM-nya juga memang tidak bisa yang terlalu umum, mungkin harus ada pelatihan khusus atau apa yang diarahkan ke sana.

Kita mempunyai SDM, itu sering disampaikan dalam berbagai kesempatan, maka kenapa kebijakan kita itu mengarah pada perdagangan dan pariwisata oleh karena SDM. Jadi kita mengarah ke kreatif, makanya walikota jalan-jalan ke luar negeri kan jualan smarcity. Jadi yang dijualnya kreatifitasnya. Jasa dan perdagangan ada, pariwisata itu yang lebih mengemuka. Hanya memang dari awal, wakil ketua DPRD juga belum melihat bagaimana itu menjadi leader. Kita ini kota wisata dari a sampai z, semuanya sudah siap melayani, bertindak sebagai kota yang memang membutuhkan wisatawan. Namun hal ini masih di tataran elite, elitenya juga belum nyambung antar komponen yang harusnya bisa bekerjasama.

Dari jawaban wakil ketua DPRD tersebut dan dilihat dari nada bicaranya, terlihat adanya ketidaksepakatan antara walikota Bandung dengan DPRD Kota Bandung, seolah-olah walikota berjalan sendiri 
tanpa adanya kesepakatan dengan DPRD Kota Bandung terhadap beberapa hal, terutama dalam pembangunan fisik di Kota Bandung. Kepala Bappeda menyatakan bahwa potensi alam, secara morfologis Kota Bandung terletak di tengah Cekungan Bandung, yaitu kawasan yang memiliki nilai strategis nasional. Kota Bandung juga termasuk dalam Daerah Pengaliran Sungai, sehingga mempunyai nilai penting karena merupakan pemasok utama waduk Saguling dan Cirata yang digunakan sebagai pembangkit listrik, pertanian, dan lainnya. Potensi SDM, diantaranya penduduk. Penduduk merupakan modal dasar keberhasilan pembangunan.. Besaran, komposisi, dan distribusi penduduk akan mempengaruhi struktur ruang dan kegiatan sosial dan ekonomi masyarakat. Seluruh aspek pembangunan memiliki korelasi dan interaksi dengan kondisi kependudukan yang ada, sehingga informasi tentang demografis memiliki posisi strategis dalam penentuan kebijakan.

Lingkungan fisik Kota

Bandung yaitu lingkungan biotik adalah lingkungan yang menyangkut dengan alam. Lingkungan kerja fisik, yaitu semua keadaan yang berbentuk fisik yang terdapat di sekitar tempat kerja yang dapat mempengaruhi pegawai dan kelembagaan baik secara langsung maupun tidak langsung. Lingkungan non fisik Kota Bandung, yaitu adalah lingkungan yang menyangkut dengan orang. contohnya sekolah, lingkungan keluarga. lingkungan kerja non fisik, yaitu semua keadaan yang terjadi yang berkaitan dengan hubungan kerja baik hubungan dengan atasan maupun hubungan sesama rekan kerja, ataupun hubungan dengan bawahan. Lingkungan kerja yang baik dapat mendukung pelaksanaan kerja sehingga karyawan memiliki semangat bekerja dan meningkatkan kinerjanya.

Selain itu, pemahaman Kepala Bappeda tentang potensi SDA, SDM dan Sumber Daya Buatan di Kota Bandung, bahwa Kota Bandung SDA-nya sangat kurang, Pemahaman Kepala Bappeda tentang lingkungan kota, ada pemahaman yang berbeda. Kalau lingkungan dalam arti fisik, yaitu kualitas air, udara, dan tanah. Karena di Kota Bandung banyak kendaraan bermotor, tentu saja emisinya kan pasti perlu diperhatikan sekali karena ini daerah perkotaan, jadi tidak sehat juga.

Air itu lebih ke pembuangan limbah-limbah, yang misalnya limbah B3. Limbah itu kan juga limbah domestik yang belum terlayani semua oleh sistem pengolahan limbah, kita baru $40 \%$ yang diolah secara terpusat. Kebanyakan pakai sistem septitenk, itu kan lama-lama bisa mencemari juga. Banyak di daerah kumuh itu dia buang langsung, misalnya tidak diproses lagi melalui septitenk. Septitenk yang ada di Bojongsoang belum terkoneksi ke rumah tangga.

Prioritas utama yang perlu dilakukan oleh Bappeda, kalau di Bappeda yang dipikirkan bukan 
Bappeda saja, tetapi tingkat kota. Kalau bicaranya tentang Bappeda sendiri, prioritasnya pasti peningkatan kualitas SDM Bappeda. Kalau bicara internal Bappeda, bagaimana SDM-nya semakin berkualitas, bagaimana kantornya lebih bagus, SOP nya tersusun dengan baik. Sedangkan kalau proritas kota sudah termuat di dalam RPJMD maupun di dalam RKPD.

Faktor-faktor yang mendukung dan menghambat kinerja birokrasi di lembaga, kalau di Bappeda dulu ya, kalau yang mendukung terlihat adanya leadership dari kepala daerah. Jadi kalau leadership-nya misalnya terkait dengan mendorong orang untuk tidak korupsi atau dia memberi contoh kemudian dia sendiri mempunyai inovasi dan sebagainya, jadi memang masih sangat bergantung kepada leadaerership kepala daerah, dan kebetulan ketika kepala daerahnya punya leadership yang bagus, tentu hal ini menjadi faktor pendukung. Kalau hal lain yaitu budaya kerja, dapat dikatakan sebagai faktor pendukung maupun faktor penghambat. Tetapi budaya kerja itu biasanya termasuk faktor penghambat. Faktor penghambat juga biasanya datang dari aturanaturan yang kurang sinkron. Sebenarnya aturan yang ada sangat terpusat yang sudah disentralisasi, jadi membuat aturan-aturan yang diantaranya kementriannya sendiri juga masih belum sinergi, itu ada satu sama lain yang tidak saling mendukung, kemudian ada yang mereka membuat aturan menyamaratakan semua daerah, padahal kita kan bhineka tunggal ika, semuanya sangat beragam, mungkin kalau membuat aturan itu perlu ada hal-hal yang tidak terlalu rigid. Jadi kalaupun mau membuat peraturan yang sangat mempelajari clustercluster atau klasifikasi dari setiap daerah, karena itu range-nya sangat lebar, tidak bisa kota kecil, menengah, sedang misalnya tidak bisa seperti itu.

Berbeda dengan pendapat dari Bagian Umum dan Kepegawaian BPLH Kota Bandung. Kalau alam kita harus mensyukuri, Bandung kata orang indah. Kalau manusia di Bandung banyak orang pintar, produktif, kreatif. Kalau kita bisa mengajak orang untuk turut bekerja sama terkait pengelolaan lingkungan hidup, jadi mudah. Di BPLH SDM nya kurang orang, hanya 64. Kalau semua ke lapangan, jadi sepi, kurang bila dibandingkan dengan di Dinas Pertamanan. Di BPLH banyak juga yang menerima pindahan dari kabupaten lain, tidak pernah ditolak, apapun background- nya, karena BPLH butuh orang. Misalkan satu sub bid 3 staff untuk membina semua kecamatan eco office sehingga BPLH bekerjasama dengan dinas lain. Selain kuantitas, kualitasnya juga kurang. Banyak orang lama, kadang-kadang senior, itu susah diajak bekerja. Sumber daya buatan secara fisik Bandung bagus seperti ada taman.

Pemahaman tentang lingkungan wilayah kerja, dahulu 
tahun 2000-an masih Bappelda dan

LH terpisah, lalu disatukan menjadi BPLH. Jadi orang-orang sekarang merupakan gabungan dari dua lembaga itu. Mengenai prioritas utama yang perlu dilakukan oleh BPLH adalah sesuai dengan Renstra, tetapi responden tidak menunjukkan Renstranya. Adapun pembangunan lingkungan hidup yang dilakukan selama ini, bahwa kebijakan yang diterapkan membawa perubahan, tentu atas dorongan walikota. Kita bisa lihat dari yang adipura, kita tahun lalu hanya best effort, tahun ini (2015) kita benar-benar mendapatkan adipura. Jadi kita meningkat pengelolaan lingkungan secara umum.

Adapun pemahaman responden tentang faktor-faktor yang mendukung dan menghambat kinerja birokrasi, mengenai faktor pendukung sebenarnya kebijakan pimpinan yaitu walikota. Adapun sebagai penghambat salah satunya adalah waktu. BPLH selalu terbentur dengan DPA. Jadi, kajian tidak jelas. Menentukan kajian apapun terburuburu, tidak terevaluasi secara keseluruhan. Kadang-kadang yang tidak perlu ada, tetapi yang perlu tidak ada.

Setiap program punya target masing-masing, sesuai Renstra, tidak harus $100 \%$, sesuai dengan RPJM. Kalau eco office, masing-masing kecamatan berlomba-lomba untuk bagus. Sekalipun juara tahun kemarin eco office belum ideal. Setidaknya sudah ada komitmen.
Kalau udara, kita pernah tahun kemarin, kualitas udara perkotaan kita juara. Kalau air, sungai, kita agak susah, karena posisi hulu sungai di Bandung Barat, ke sini bisa kotor. Kalau tanah, kita masih kurang. Pengawasan tanah belum tren. Peraturan juga belum ada turunannya, belum lengkap. Kita masih sebatas sampel lokasi tanah, masih sekadar pengkajian, belum jauh.

Mengenai pemahaman Direktur Utama PD Kebersihan tentang potensi SDA, SDM, dan Sumber Daya Buatan di Kota Bandung, bahwa SDA sudah berkurang karena dihabisi untuk bangunan-bangunan, baik oleh pihak swasta maupun perorangan. Rencana ke depan, pak walikota mau membangun bangunan-bangunan yang vertikal. Untuk SDM sudah bagus menjadi potensi banyak orangorang kreatif yang ada di Bandung. Banyaknya FO dan industri kreatif ya secara SDM sudah bagus. Kalau untuk sumber daya buatan di Kota Bandung sudah meningkat dan dioptimalkan seperti taman-taman, di Babakan Siliwangi dan ruang-ruang terbuka hijau lainnya terus dibangun.

Pemahaman tentang prioritas utama yang perlu dilakukan oleh lembaga, kalau ditanya dalam waktu dekat ini, penghargaan Adipura, Bandung bersih. Tetapi susahnya adalah bagaimana kita mempertahankannya untuk waktu berikutnya. Mempertahankan itu lebih susah daripada memenangkannya. 
Pembangunan yang dilakukan selama ini menurut Direktur Utama PD Kebersihan sudah bagus. Bandung banyak berubah semenjak kepemimpinan walikota sekarang, infrastruktur sudah banyak berkembang, penyerapan dana dari CSR untuk pembagunan juga sudah optimal, dan banyak apresiasi dari berbagai daerah lain ke Kota Bandung dilihat dari kunjungankunjungan daerah Kota Bandung ini dijadikan contoh.

Pemahaman Direktur Utama PD Kebersihan tentang faktor-faktor yang mendukung dan menghambat kinerja birokrasi, kalau yang mendukung ya kepemimpinan pak walikota yang konsen terhadap lingkungan, sekarang walikota itu sering memantau kinerja birokrat, kalau ada yang tidak melayani dengan baik ditegur. Sekarang banyak perubahan di birokrat. Kalau yang menghambat yaitu gaji. Tetapi menurut Direktur Utama PD Kebersihan merupakan tugasnya untuk meningkatkan gaji para karyawan, sehingga PD Kebersihan ke depannya harus profit.

Bagaimana pemahaman pembangunan yang dilakukan selama ini ? Pembangunan selama ini sudah sesuai dengan arahan yang tercantum dalam peraturan perundang-undangan berupa Rencana Jangka Panjang, Rencana Jangka Menengah, maupun Rencana Kerja Tahunan. Namun demikian hasilnya ada yang sudah maksimal namun juga ada yang belum. Begitu pula keterlibatan masyarakat nampaknya belum begitu optimal, contohnya masih banyak masyarakat yang membuang sampahnya di sungai, dan banyak masyarakat yang belum memisahkan sampah yang organik dan yang non-organik.

Bagaimana pemahaman tentang tahapan pembangunan ? Tahapan pembangunan adalah hal yang tidak bisa tidak harus dilakukan, karena tidak mungkin pembangunan dilakukan tanpa tahapan. Tahapan pembangunan merupakan sesuatu yang harus dilakukan sesuai dengan ketentuan peraturan perundang-undangan yaitu tahapan pembangunan jangka panjang (20 tahunan), tahapan jangka menengah (5 tahunan), dan tahapan satu tahunan (rencana kerja pembangunan daerah). Pada saat ini, pada pembangunan satu tahunan selalu dimulai dari Rakorbang mulai dari tingkat RW, kelurahan, kecamatan dan terakhir di tingkat Kota Bandung. Hal ini dimaksudkan supaya aspirasi dari masyarakat bisa diaplikasikan.

Apakah selama ini ada evaluasi tentang pembangunan Kota Bandung ? Evaluasi pembangunan kota merupakan sesuatu yang dilakukan baik oleh instansi pengawas internal seperti Inspektorat, dan DPRD maupun lembaga dari luar seperti BPK dan BPKP. Pemeriksaan dipandang sebagai suatu evaluasi sampai sejauh mana kesesuaian dengan anggaran yang ada, dan tujuan sasaran pembangunan. Evaluasi merupakan satu kesatuan dengan pengendalian, 
yang hasilnya dapat dijadikan bahan pula untuk penyusunan rencana pembangunan. Dengan demikian pelaksanaan evaluasi ini juga mengikuti tata caranya sebagaimana ketentuan Peraturan Daerah Nomor 07 Tahun 2008 tentang Tahapan, Tata Cara Penyusunan, Pengendalian dan Evaluasi Pelaksanaan Rencana Pembangunan Serta Musyawarah Pembangunan Daerah.

$$
\text { Bagaimana pemahaman }
$$

tentang faktor-faktor yang mendukung dan menghambat kinerja birokrasi ? Seberapa jauh tingkat kemampuan pelaksanaan tugas-tugas organisasi dari suatu sistem yang telah ditentukan berdasar faktor situasional pada proses pelaksanaan dalam organisasi. Dengan demikian, maka penampilan sebuah organisasi dipengaruhi oleh dua faktor yaitu: faktor internal organisasi dan faktor eksternal yang berupa lingkungan. Kualifikasi dan kompetensi birokrat harus diakui masih cukup jauh dari harapan yang berdampak pada rendahnya kinerja pegawai. buruknya sistem. Upaya mereformasi birokrasi sering terhalang oleh sistem yang berlaku yang kurang mendukung perwujudan birokrasi ideal. Contohnya, sistem penggajian (remunerasi) belum maksimal untuk mendorong peningkatan kinerja. Antara pegawai yang berprestasi dan yang tidak berprestasi atau antara yang berdisiplin dan yang bermalasmalasan, memperoleh gaji dan perlakuan relatif sama.
Kalau SDM sebenarnya, industri banyak bahan mentahnya dari luar. Artinya, SDA adalah bahan mentah yang sudah tercipta. Banyaknya bahan mentah dari luar Kota Bandung seperti dari Kabupaten Bandung, dari Garut, Cimahi, Sumedang. Sebenarnya Bandung sudah kota jasa dan industri karena bahan mentah sudah tidak ada di sini. Kalau SDM termasuk unggul dibanding daerah lain, karena kampus-kampus bagus di Bandung ada Unpad, ITB, UPI, swasta juga banyak yang bagus. Berarti kalau SDM sebenarnya ada di sini. Hanya saja lulusannya banyak juga yang mengabdi di daerah bahkan negara lain. Potensi SDM bagus di sini, mencetak SDM bagus. Hanya saja tergantung itu mengabdi di mana, apakah di Bandung atau tidak.

SDM seperti ini karena salah rekrut, yang berkualitas baru dari tahun 2006 ke sini, sebelum 2006 tidak kapabel. Orang-orang yang seperti itu tidak akan mau bicara seperti ini karena berbicara tentang dirinya sendiri. Bagaimana pemahaman Bapak tentang lingkungan wilayah kerja? Lingkungan fisik dan non fisik. Di sini tidak semua orang punya komputer, tidak semua orang bisa memakai komputer, tidak semua orang bisa menyalakan komputer, tidak semua orang bisa shut down komputer.

Iklim per bidang lebih eksklusif, individualis, kalau sekretariat tidak, karena mengayomi semua bidang. Kalau bidang 
mementingkan kepentingan masingmasing, kalau yang satu banyak tugas yang lain tidak mau membantu, kalau tidak diperintahkan kepala dinas, tidak mau bekerja. Kalau sekretariat saling bantu membantu.

Bagaimana pemahaman tentang prioritas utama yang perlu dilakukan oleh Dinas ? Pembenahan tata kelola organisasi. Pertama, hal ini karena tupoksi masih abstrak. Kepala dinas, sekretaris, kepala bidang, kepala seksi belum bisa menerjemahkan tupoksi itu ke dalam bentuk paket-paket pekerjaan yang siap dialokasikan ke bawahannya. Kedua, pejabat struktural ini tidak menguasai all section dari semua pekerjaan bawahannya. Artinya, karena tidak menguasai, dia mempunyai ketergantungan yang amat besar pada anak buah. Ketiga, fungsi training tidak berjalan. Untuk itu, kalau mau cepat harus dibenahi tata kelola organisasinya. Anak buah bukan tidak mau bekerja keras tapi tidak mau diperlakukan tidak adil, yang pintar jadi kebanyakan tugas tapi gaji sama dengan yang tidak kerja. Yang malas tambah malas, yang rajin jadi overload. Jadi yang banyak tugas cari pelampiasan, seperti S2 atau kalau perempuan hamil, kalau laki-laki pindah ke dinas lain. Kondisi ini perlu diketahui oleh orang ilmu pemerintahan.

Untuk sumber daya alam, diakui oleh informan di Kota Bandung ini sangat minim. Keduanya sepakat sumber daya manusia (SDM) lah yang sebaiknya diutamakan. Sebagai kota jasa,
Bandung juga memiliki sumber daya manusia yang melimpah karena banyaknya Perguruan Tinggi.

\section{Renewal}

Berdasarkan hasil wawancara dengan pertanyaan tentang bagaimana pemahaman tentang apa yang dilaksanakan di bidang fisik, bidang sosial, dan bidang budaya, terungkap bahwa pembangunan yang dilakukan oleh Pemerintah Kota Bandung sudah mencakup ketiga bidang tersebut. Pembangunan di bidang fisik nampak dilakukan pada sektor infrastruktur kota seperti jalan dan trotoar, pembangunan perumahan bagi masyarakat seperti pembangunan rumah susun, dan sebagainya. Pembangunan di bidang sosial, nampak dilakukan pada sektor kesehatan, pendidikan, dan keagamaan. Begitu juga dengan pembangunan di bidang sosial, dilakukan misalnya dengan menggiatkan kehidupan kesenian tradisional, olahraga tradisional, peningkatan budaya lokal, dan sebagainya.

Terhadap masalah ini peneliti mendapat penguatan dari hasil wawancara dengan Wakil Ketua DPRD Kota Bandung, bahwa pembangunan kota di bawah kepemimpinan walikota sekarang ada peningkatan khususnya dalam pembangunan taman kota. Orientasi lembaga yang ada di Kota Bandung sudah tepat dan sesuai untuk mencapai visi dan misi Kota Bandung, baik dalam bidang pembangunan, dan pencapaian 
kesejahteraan rakyat. Haparannya, agar kinerja dari lembaga yang ada senantiasa ditingkatkan supaya selalu mampu memberikan pelayanan terbaik bagi masyarakat Kota Bandung.

Apakah sistem penggajian sudah sesuai dengan kinerjanya ? Sistem penggajian yang ada belum sesuai dengan kinerja dari pegawai. Pegawai yang kinerjanya kurang ataupun yang baik sekali, gajinya sama. Apakah learning system yang berlaku saat ini sesuai dengan yang diharapkan ? Sistem pembelajaran yang ada sudah cukup sesuai dengan yang diharapkan, mengingat adanya Monitoring dan Evaluasi, serta pendidikan dan latihan SDM untuk peningkatan kompetensi. Namun demikian, masih ada beberapa hal yang belum tercapai seperti pendidikan dan latihan untuk meningkatkan jumlah fungsional tertentu seperti Diklatnya terasa kurang, dan tidak setiap tahun ada. Pemerintah Kota Bandung telah melakukan inovasi, terbukti dengan adanya Program Inovasi Pembangunan dan Pemberdayaan Kewilayahan.

Berdasarkan pertanyaan yang diajukan kepada Kepala Bappeda tentang sosial dan budaya Kota Bandung, secara khusus belum tahu karena belum ada riset. Kalau orang Bandung ini kan heterogen banget, tetapi mereka ada kecenderungan kurang patuh terhadap aturan-aturan, beda dengan kalau di Jawa itu masyarakatnya manut banget sama pimpinan, kalau kita lebih demokratis, lebih legaliter antara pimpinan dengan warganya, ini ada keuntungan dan kerugiannya. Kalau dari sisi keuntungannya karena orang Bandung itu sangat heterogen kemudian juga demokratis tetapi dia lebih terbuka terhadap perbedaan pendapat, kemudian juga pendatang, jadi sangat toleran, relatif lebih toleran dibanding dengan beberapa daerah lain, walaupun tetap saja suka ada yang protes.

Walikota yang sekarang kan beliau menyadari bahwa sekarang itu sudah tidak cocok dengan pemerintahan yang bersikap seperti bermain di jarak, jadi katanya sekarang dia menganut pemerintahan yang sifatnya horizontal. Mungkin itu lebih cocok di Kota Bandung, belum tentu cocok di daerah lain. Jadi dia benar-benar tidak memberi jarak dengan warga, duduk bareng, ini kecenderungannya Jokowi juga bisa jadi presiden juga karena tidak memberi jarak. Ya ada plus-minusnya, dia kurang suka diatur, cenderung melanggar aturan, tetapi memberi ruang untuk kreatifitas. Tinggal memang ada nilai-nilai universal yang tidak boleh yang memang harus diajarkan, tetap harus dididik itu ketika soal etika, sopan santun, kejujuran, itu kan sebuah nilai universal yang memang harus diterapkan. Segimana heterogennya, segimana egaliternya, kita memang harus tetap menerapkan kesantunan, nah ini yang pak walikota harapkan, ini yang namanya pendidikan khusus. Di Kota Bandung ini gerakan-gerakan gotong royongnya 
diangkat, karena di masyarakat heterogen itu kan harus ada upaya ekstra untuk menumbuhkan itu, apalagi di kota-kota besar itu kan kecenderungan orang individualis.

Mengenai pemahaman tentang orientasi lembaga, arah dan harapan dari lembaga, menurut Kepala Bappeda bahwa ke depan, sebagai Kepala Bappeda di sini mengharapkan memang lebih professional. Mungkin ada ukuranukuran yang bisa diterapkan, karena bagaimana professional di birokrasi apakah sama dengan yang disebut professional di desa (?), artinya ketika dia professional, dia harus memiliki integritas, dia harus memiliki kompetisi, ada skill-skill yang memang dia harus miliki dan itu diterapkan dalam proses rekruitmen ke depan sehingga kan itu bagus tidaknya sebuah organisasi apakah dia bisa menjalankan fungsinya memang di SDM-nya, menjadi modal utamalah, human capital itu bagi lembaga seperti Bappeda. Jadi human capital itu menjadi sesuatu yang pokok, sehingga proses rekruitmennya harus benar- benar selektif, dan benarbenar memenuhi kriteria tertentu, kemudian ditunjang juga oleh sarana prasarana kerja, dan ditunjang juga oleh aturan-aturan yang memang bisa mendukung ke arah sana.

Dengan mengajukan pertanyaan apakah learning system yang berlaku saat ini sudah sesuai dengan yang diharapkan, Kepala Bappeda menyatakan belum, tetapi kita selalu berusaha. Makanya
Bappeda itu selalau memberikan ruang, jadi Kepala Bappeda tidak menerapkan sesuatu yang disiplin ketat seperti di pabrik, mereka lebih banyak proses dialog, proses diskusi, nah disitulah proses learning system.

Inovasi-inovasi di Kota Bandung ini, mereka melihat dengan walikota yang sekarang, karena memang beliau itu menjadi salah satu main strategy, inovasi, bahkan beliau mewajibkan setiap dinas itu harus berinovasi. Menjanjikan sih, kemarin sempat dibahas bahwa ketika dia memiliki inovasi akan ada promosi. Tetapi itu kan harus diatur dalam sebuah regulasi, jadi terbuka proses promosi dan sebagainya apalagi posisi-posisi itu sangat terbatas, dan jabatan, orang masih cenderung structural minded jadi itu yang dikejar. Ya tidak salah karena posisi-posisi fungsional itu kurang berkembang karena dari pemerintahnya sendiri penghargaannya masih kurang, termasuk fasilitasnya.

Adapun menurut pihak dari BPLH, apa yang dilaksanakan oleh BPLH baik dari segi fisik, sosial atau budaya, bahwa BPLH tidak boleh membangun secara fisik, karena hanya perumus kebijakan. Dari segi sosial, BPLH melakukan outbond setahun sekali. Sebenarnya ada beberapa bidang punya kegiatan, kalau ada kegiatan yang ramai, seperti hari lingkungan, semua datang. Kalau yang outbond itu khusus hanya setahun sekali karena tidak ada anggarannya. Tentang orientasi, arah, dan harapan dari 
BPLH, yaitu bisa menciptakan lingkungan hidup yang berkualitas sehingga masyarakat bisa hidup nyaman.

Mengenai inovasi-inovasi yang sudah dilakukan oleh BPLH, di Bandung banyak. Seperti biopori, biodigester, taman tematik. Penegakan Perda K3 melalui posterposter lucu. Itu yang termasuk inovasi bidang lingkungan. Lalu group Kepala SKPD di whatsapp juga ada. Kalau ditegur oleh walikota di group kan malu. Rapim sebulan sekali juga rutin, tidak seperti sebelum era Ridwan Kamil, dahulu mereka jarang rapim.

Bagi Direktur Utama PD Kebersihan, bahwa Bandung sudah besar walau dengan itu perkembangan teknologi sudah canggih, namun dengan begitu jadi semakin individualis manusianya. Kurang komunikasi, face-to-facenya, walau untuk komunikasi lebih mudah karena teknologi, dalam beberapa detik saja sudah dapat mendapat laporan dari orang-orang di lapangan, tetapi ya tatap mukanya menjadi jarang sekali. Budaya masih bagus, seperti saung angklung Udjo itu kan masih ada, setiap hari selalu ada pertunjukan, dengan penonton selain masyarakat dari Kota Bandung, juga masyarakat dari luar Kota Bandung bahkan dari luar negeri. Hanya untuk budaya lokalnya sendiri (yang masih alami) sudah jarang.

Mengenai pemahaman tentang orientasi lembaga, arah dan , harapan dari lembaga, menurut Direktur
Utama PD Kebersihan, Bandung bisa bersih secara konsisten dan mendapatkan adipura, dan kedepannya juga bisa mempertahankan. Yang kedua bisa profit PD Kebersihan kedepannya, itu yang paling penting.

Adapun inovasi-inovasi yang akan dan sudah dilakukan oleh PD Kebersihan, mungkin yang paling dekat, di PD Kebersihan semua akan berbasis IT. Jadi Bandung Command Center akan diduplikasi di sini. Kedua, kita sekarang akan bangun pengelolaan-pengelolaan sampah, biodigester yang cukup besar, jadi kan sekarang PD Kebersihan sedang membangun Bank Sampah Kota Bandung di Kiaracondong. Nanti PD Kebersihan juga akan membangun biodigester. Jadi biodigester itu dari sampah-sampah yang bekas makanan kita jadi gas, dan sekarang sudah dipakai di beberapa tempat, tetapi masih skala kecil, sehingga orang tidak perlu beli gas. Bagi PD Kebersihan, sampah menjadi berkurang. Begitu sampah berkurang, yang diangkut kan sedikit, biaya jadi turun, terus rumah penduduk juga jadi efisien, kemudian orang tidak perlu beli tabung gas. Ketiga, yang penting bagi PD Kebersihan adalah edukasi untuk masyarakat, bahkan masyarakat didorong untuk memilah sampah mana yang organik, mana yang nonorganik. PD Kebersihan akan membeli dan dibayar secara cash. Jadi biar masyarakat di rumah memilah-milahkan, karena sampah itu kan ada dua, bisa menjadi 
musibah, dan bisa menjadi barokah artinya bisa jadi ada nilai ekonomisnya. Apabila inovasi yang dilakukan ini benar-benar berhasil, maka Kota Bandung menjadi lebih bersih lagi dan masyarakat tidak perlu membeli gas.

\section{SIMPULAN \\ REKOMENDASI \\ Simpulan}

DAN

Berdasarkan hasil wawancara dengan Wakil Ketua DPRD, Kepala Bappeda, Pimpinan BPLH, Direktur Utama PD Kebersihan, diperoleh informasi yang saling mendukung transformasi manajemen pemerintahan di Kota Bandung.. Dimensi pertama adalah reframing. Dasar hukum visi dan misi pemerintah Kota Bandung adalah Peraturan Daerah Kota Bandung Nomor 03 Tahun 2014 tentang Rencana Pembangunan Jangka Menengah Daerah Tahun 2013-2018. Dalam Perda tersebut disebutkan bahwa visi Kepala Daerah Tahun 2013-2018 yaitu Terwujudnya Kota Bandung Yang Unggul, Nyaman dan Sejahtera, sejalan dan selaras dengan Visi Daerah yaitu "Kota Bandung Yang Bermartabat'. Artinya telah ada penambahan visi dari visi daerah sebelumnya, sehingga dapat dikatakan telah ada reframing dengan pergantian Walikota Bandung pada tahun 2013 dari Dada Rosada kepada Ridwan Kamil. Pemahaman tentang visi dan misi dalam aspek perencaraan pembangunan, sifatnya menjadi sesuatu yang menjadi cita-cita semua orang. Kalau nyaman terkait dengan liveable, kalau unggul itu harus menjadi yang terbaik diantara semua usahanya. Sejahtera itu menyangkut ke masalah ekonomi, jadi wealthy, kemakmuran, sejahtera. Itu sebenarnya bisa diterapkan di mana saja, tidak spesifik, jadi semua pasti cocok dan semua upaya pemerintah pada umumnya di semua kota pasti akan mengarah ke sana. Adapun visi dan misi BPLH dan PD Kebersihan memiliki kesamaan, yaitu intinya bahwa Bandung ini harus ramah lingkungan dan bersih.

Dimensi kedua yaitu restructuring. Di Kota Bandung berlangsung cukup dinamis sesuai dengan perkembangan Kota Bandung saat ini. Kota Bandung yang sedang berkembang maka banyak dilakukan penyesuaian dan juga inovasi apakah itu dengan keberadaan perusahaan daerah seperti kondisi sekarang apakah harus tetap dipertahankan dari sisi pembiayaan pembangunan yang begitu besar dan menuntut penerimaan yang lebih banyak, kalau hanya mengandalkan dari pendapatan daerah termasuk mengandalkan SKPD yang ada itu juga harus dipertimbangkan, tidak mungkin membentuk semacam lembaga yang sifatnya lebih terbuka dari yang sifatnya sisi pengelolaan keuangan maupun pengelolaan regulasinya, karena ada istilah di pemerintahan hal itu sangat rijid, padahal sekarang itu banyak dari pemerintahan luar negeri yang datang dengan membawa modal mau berinvestasi tapi sering juga terkendala dengan regulasi yang 
seolah - olah mengikat. Disinilah perlu inovasi dan juga di satu sisi juga melakukan pembangunan tanpa harus melanggar aturan tapi juga di satu sisi orang yang ingin masuk yang ingin berinvestasi juga mudah dan tidak dipersulit, demikian berbagai upaya di atas yang sedang diupayakan regulasinya.

$\begin{array}{ccr}\text { Dimensi } & \text { ketiga } & \text { yaitu } \\ \text { revitalization. } & \text { Dalam } & \text { hal }\end{array}$

revitalization ada sedikit dilakukan namun tidak dibarengi dengan perubahan regulasi yang memadai. Karna mengenai Sumber Daya Alam di Kota Bandung terutama berupa lahan, semakin lama semakin berkurang karena lahan yang ada sudah hampir semuanya dipenuhi dengan bangunan. Di Kota Bandung yang bisa dibanggakan berupa Sumber Daya Manausia dan Sumber Daya Buatan.

Dimensi terakhir yaitu renewal , berkaitan dengan keadaan fisik yang secara keseluruhan belum semuanya baik. Dalam bidang sosial masih perlu ada edukasi bagi pembangunan SDM yaitu pelayanan kepada masyarakat. Demikian juga dalam pemberian insentif, karena sebagai pegawai harapannya dari sisi kesejahteraan harus meningkat dan semua harus merasakan. Kepemimpinan yang sekarang ini telah melakukan inovasi baik dari segi hubungan komunikasi dengan pegawai melalui media sosial secara terbuka, kemudian juga ke depan dengan kepemimpinan yang sekarang terdapat lonjakan yang cukup besar yaitu inovasi untuk memanfaatkan teknologi informasi sehingga hal ini disambut baik oleh para pegawai.

\section{Rekomendasi}

Telah terjadinya reframing terhadap visi dan misi Kota Bandung. Ridwan Kamil sebagai Walikota telah menambahkan konsep unggul, nyaman dan sejahtera serta konsep Bandung Juara yang menurut Wakil Ketua DPRD Kota Bandung khusus untuk Bandung Juara ini hanya penyemangat tidak ada dokumen formalnya. Hal ini yang menyebabkan salah satu kelemahan terhadap reframing yang telah dilakukan, sebaiknya walikota mendekat ke DPRD untuk menciptakan regulasi-regulasi lanjutan sebagai tindak lanjut adanya reframing visi dan misi Kota Bandung.

Untuk sumber daya alam, sebaiknya SDM-lah yang sebaiknya diutamakan. Sebagai kota jasa, Bandung juga memiliki sumber daya manusia yang melimpah karena banyaknya Perguruan Tinggi. Selain itu, potensi SDM biasanya memiliki inovasi dan memberikan dukungan, meskipun sifatnya masih individual.

Dalam hal revitalization dan renewal ada sedikit dilakukan namun tidak dibarengi dengan perubahan regulasi yang memadai contohnya tentang konsep Bandung Juara yang merupakan suatu renewal dalam menyemangati aparat untuk giat meraih prestasi dalam berbagai bidang sehingga menjadikan Bandung juara (kahiji). Sebaiknya 
dibarengi dengan memberikan landasan hukum formal setingkat Perda dan didukung kekuatan politik di lembaga DPRD Kota.

\section{DAFTAR PUSTAKA}

Barzelay, Michael. 1992. Breaking Through

Bureaucracy. Berkeley

Creswell, John W. 2012. Research Design : Pendekatan Kualitatif, Kuantitatif, dan Mixed. Edisi Ketiga. (Penerjemah : Achmad Fawaid). Yogyakarta : Pustaka Pelajar.

Gouillart, Francis J. dan James N. Kelly. 1995. Transforming The Organization. New York : McGraw-Hill Inc.

Held, David (ed). 1990. New Forms Of Democracy. London : SAGE, 1986 dan David Held. Models of

Democracy.Cambridge : Polity Press.

Ingraham, Patricia W., Romzek, Barbara S dan Associates. 1994, New paradigms For Government, Issues For The Changing Pulic Service. San Francisco : Jossey Bass Publishers.

Jilson, Calvin dan James F. Hollifield. 2000. Pathways To Democracy. $\quad$ London: Routledge

Ndraha, Taliziduhu. 2005. Kybernologi, Rekonstruksi Sebuah Ilmu
Pemerintahan. Jakarta: PT Rineka Cipta.

Nugroho, Riant. 2008. Public Policy. Jakarta : PT. Gramedia.

Osborne, David dan Peter Plastrik. 1997. Banishing Bureaucracy. New York: Addison Wesley Publishing Company.

Redjo, Samugyo Ibnu. 2009. Transformasi Manajemen Pemerintahan Kota. Bandung: AIPI

Sugiyono. 2007. Metode Penelitian Kuantitatif kualitatif Dan $R$ \& $D$. Bandung : Alfabeta.

Wasistiono, Sadu. 2003. Kapita Selekta Manajemen Pemerintahan Daerah. Edisi Revisi. Fokusmedia, Bandung.

Kristiadi JB. 1997. Perspektif Administrasi Publik Menghadapi tantangan Abd 21 dalam Jurnal Administrasi dan Pembangunan. PP Persadi:

Pearce, John. A H., dan Richard B. Robinson. 2000. Strategic Management:

Formulation,Implementation, and Control $7^{\text {th }} \mathrm{Ed}$. Singapura : Irwin McGraw-Hill.

Undang-undang Republik Indonesia Nomor 32 Tahun 2009 tentang Perlindungan dan Pengelolaan Lingkungan Hidup

Peraturan Daerah Kota Bandung Nomor 12 Tahun 2009 tentang Perubahan Atas Peraturan Daerah Kota 


Bandung Nomor 12 Tahun
2007 tentang Pembentukan
dan Susunan Organisasi
Lembaga Teknis Daerah Kota
Bandung
Peraturan Daerah Kota Bandung
Nomor 06 Tahun 2011
tentang Penyelenggaraan,
Perlindungan
Pengelolaan
Hidup Lingkungan

